\title{
THE CULTURAL NEGOTIATION OF BEING SHIA AND MADURESE:
}

\section{How It Can be Reconciled?}

\author{
Abdus Sair*, Yelly Elanda** \\ *Sosiologi, Universitas Wijaya Kusuma, Surabaya, Indonesia \\ **Sosiologi, Universitas Wijaya Kusuma, Surabaya, Indonesia \\ email: "syairbook@gmail.com, ${ }^{* *}$ yelly.elanda@gmail.com
}

\section{ABSTRACT}

The life of the Sampang Shia community in the refugee camps remains regretful. They are considered a heretical sect by the Indonesian Council of Religious Scholars (MUI), expelled and face complex social problems. Various policies have been attempted, but have not had an impact. This article aims at explaining the reasons for the emergence of discrimination and expulsion of the Sampang Shia community and how they negotiated as a hated Shia minority as well as a "good" Madurese community. Can they be reconciled? This article was written based on field research using a qualitative method with a narrative approach. The data were obtained by conducting in-depth interviews with leaders or figures as well as Shia refugees in the refugee camps. This article shows that the Shia community of Sampang was expelled because of a deviant discourse produced by the MUI. Meanwhile, their negotiation as Shia they hate is to remain a good Madurese; obey the kiai, continue to speak Madurese, continue to work as a cultural spirit, and continue to live life while looking for a cultural way back.

\section{ABSTRAK}

Kehidupan masyarakat Syiah Sampang di kamp pengungsian tetap disesalkan. Mereka dianggap aliran sesat oleh Majelis Ulama Indonesia (MUI), diusir dan menghadapi masalah sosial yang kompleks. Berbagai kebijakan telah diupayakan, namun belum berdampak. Artikel ini bertujuan untuk menjelaskan alasan munculnya diskriminasi dan pengusiran komunitas Syiah Sampang dan bagaimana mereka bernegosiasi sebagai minoritas Syiah yang dibenci sekaligus komunitas Madura yang "baik". Bisakah mereka berdamai? Artikel ini ditulis berdasarkan penelitian lapangan dengan menggunakan metode kualitatif dengan pendekatan naratif. Data diperoleh dengan melakukan wawancara mendalam dengan tokoh atau tokoh serta pengungsi Syiah di tempat pengungsian. Artikel ini menunjukkan bahwa komunitas Syiah Sampang diusir karena wacana menyimpang yang dihasilkan oleh MUI. Sedangkan negosiasi mereka sebagai Syiah yang mereka benci adalah tetap menjadi orang Madura yang baik; taat pada kiai, terus berbahasa Madura, terus berkarya sebagai spirit budaya, dan terus menjalani kehidupan sambil mencari jalan kebudayaan untuk kembali.
ARTICLE HISTORY

Received 15 February 2021

Accepted 13 June 2021

\section{KEYWORDS}

Cultural negotiation; Shia; Madurese 


\section{Introduction}

This article will discuss the social life of the Sampang Shia refugees in the refugee camp (Rusunawa Jemundo) in Sidoarjo, East Java. They are people who have been expelled from their hometown in Sampang Regency. They were driven out because they were Shia. They were attacked by an anti-Shia group which was followed by arson against their settlement. The arson took place on Sunday, August 26, 2012. The action which was classified as anarchic resulted in 1 person dying, 10 people being injured, 26 houses of Shia residents burnt in Blu'ruan Village, Karang Penang District, and 23 houses of Shia residents being burned in Karang Gayam Village, SampangRegency, East Java.

The culmination of the conflict was the expulsion of Shia community from their hometown. They were initially evacuated at the Sampang Sports Hall, and then driven out of Sampang Madura. On June 20, 2013 for safety reasons and a decent life, the Shia residents were relocated to the Puspa Agro Jemundo flats, Sidoarjo Regency. There were 234 Shia refugees in the Puspa Agro flat when they first arrived in June 2013, but at the end of 2016 there were 349 people. At the beginning of 2021, their number is 347 people or 83 heads of families. ${ }^{1}$

After eight (8) years in exile, their situation has not changed. The hope of returning to their own hometown was only a dream. All efforts, including, communicating with the president have no results. On July 14 ${ }^{\text {th }}$, 2013, the representatives of Shia Sampang and Ahlulbait Indonesia (ABI) as the Shia organization met the President Susilo Bambang Yudhoyono (SBY). In the meeting, SBY states that he would return the Shia totheir hometown if they could live peacefully together with Sampang residents. But until now the promise is just a promise. ${ }^{2}$

According to Andi, ${ }^{3}$ the people of Omben actually no longer question it anymore. They have visited each other and reconciled, including the residents who attacked and the victims had made a peace agreement signed on 23 September 2013. They also agreed that the victims could return to their hometown in small groups for security reasons. It was even agreed that Tajul Muluk and his family should not have to come back to Sampang Madura. That

${ }^{1}$ Eko Pujianto, "Pengungsi Syiah Dapat Sertifikat Tanah dari Gubernur Khofifah,”Indonesia Inside, February, 2, 2021, https://indonesiainside.id/news/nusantara/2021/02/02/pengungsi-syiah-dapat-sertifikattanah-dari-gubernur-khofifah.

${ }^{2}$ Andi, "Komunitas Syiah Sampang 7 Tahun di Pengungsian, Noda Hitam di Kening Negeri Toleran," Ahlul Bait Indonesia, August, 27, 2019, https://www.ahlulbaitindonesia.or.id/berita/index.php/s13. berita/komunitas-syiah-sampang-7-tahun-di-pengungsian-noda-hitam-di-kening-negeri-toleran. ${ }^{3}$ Ibid. 
agreement was made by the residents of Shia and Tajul Muluk themself. However, the fact is that the reconciliation from the root continues to experience rejection from the religious elites in Sampang.

These elites involve many local leaders and Islamic boarding schools, and even influence the government and security elites to reject the reconciliation. Instead, they encouraged the Shia groups to repent of leaving the beliefs and practices of the Shia Islamic school and embracing Sunni teachings. ${ }^{4}$ According to Andi ${ }^{5}$ and Panggabean, ${ }^{6}$ this is actually impossible because it involves belief.

Now, after eight (8) years of exile, the Shia Sampang people still have sad stories due to the rejection above and experience uncertainty about returning to their hometown. They still have to survive in uncertainty. Several studies on the problems of the Shia community of Sampang have been carried out, such as by Munawaroh, ${ }^{7}$ Pamungkas, ${ }^{8,9}$ and Masykuri, ${ }^{10}$ but they do not focus on the issue of cultural negotiation. Therefore, this article aims at exploring the reasons for the emergence of discrimination and expulsion of the Sampang Shia community and explaining how they negotiated as a hated Shia minority group as well as Madurese community. How it can be reconciled?

This study was conducted using qualitative methods, with the narrative approach. The narrative research approach is an approach that emphasizes on phenomena or cases experienced by a person or group. Czarniawska defines this type of research as a qualitative design type where the narrative is understood as a text that is conveyed by recounting events or actions that are chronologically connected. ${ }^{11}$ The subjects in this study were Shia leaders and

4 Heyder Affan, "Mungkinkah rekonsiliasi di Sampang?" BBC, August, 1, 2013, https://www.bbc.com/indonesia/laporan_khusus/2013/08/130731_lapsus_syiah_sidoarjo_rekonsiliasi.

${ }^{5}$ Ibid.

${ }^{6}$ Rizal Panggabean, "Mungkinkah Rekonsiliasi di Sampang?" CSPS Universitas Gadjah Mada, March, 17, 2017, https://csps.ugm.ac.id/2017/03/17/mungkinkah-rekonsiliasi-di-sampang-2/

${ }^{7}$ Mundiroh Lailatul Munawaroh, Penyelesaian Konflik Sunni-Syiah di Sampang Madura (Thesis, Universitas Islam Negeri Sunan Ampel, Surabaya, 2014)

${ }^{8}$ Cahyo Pamungkas,"Mencari Bentuk Rekonsiliasi Intra-Agama: Analisis terhadap Pengungsi Syiah Sampang dan Ahmadiyah Mataram,” Epistemé: Jurnal Pengembangan Ilmu Keislaman, vol. 13, no. 1 (June, 2018 ): 114 147, https://doi.org/10.21274/epis.2018.13.1.113-147.

${ }^{9}$ Cahyo Pamungkas, "Social Resilience of Religious Minority Group: Study on Syiah Refugees in Sidoarjo and Ahmadiyah Refugees in Mataram,”Ulumuna: Journal of Islamic Studies, vol. 19, no. 2 (December,2015): 251 278,https://doi.org/10.20414/ujis.v19i2.418.

${ }^{10}$ Romel Masykuri, et. al.,Di Balik Dinding Rununawa: Mengungkap Pengalaman Komunitas Syiah Sampang di Pengungsian (Yogyakarta: Penerbit Sulur,2018)

${ }^{11}$ John W. Cresswell,Penelitian Kualitatif dan Desain Riset: Memilih di antara Lima Pendekatan (Yogyakarta: Pustaka Pelajar, 2015) 
their followers in refugee camps. The data obtained from the results of in-depth interviews with the above subjects, among others; Tajul Muluk (cleric), Hamamah (resident), Siti (resident), Taufiq (security). Meanwhile, the theory used as an analytical tool in this research is Randall Collins's integrative conflict theory. The results of the interviews were then analyzed by arranging them based on research topics, becoming a narrative and story about everyday social problems, especially about the causes of discrimination and expulsion of the Sampang Shia community, and about how they negotiated as hated Shias as well as Madurese who good as part of efforts to get justice.

\section{RusunawaWalls}

On Thursday, June 20, 2013, at 02.30 PM, all Shia residents were put into five buses provided by the Sampang Regency Government. They would be relocated to a flat in Sidoarjo Regency which is $80 \mathrm{~km}$ away from Sampang Sport Hall Madura.

Not long after, those five buses left with the Shia community leaving the Sampang Sports Hall. The group continued the tripto Bangkalan, crossing the Suramadu bridge that connects the Java island and Madura island with a length of 5,438 meters. When they reached the end of the Suramadu bridge, they entered the city of Surabaya, which is the capital city of East Java Province. From the city center, it takes approximately an hour to reach the evacuation site.

Jemundo is the name of a village located in the Taman District, Sidoarjo Regency. In this sub-district, there is a river that borders its territory with two other sub-districts, namely Karangpilang in Surabaya and Driyorejo in Gersik. The development in this area is quite fast because of its strategic location as one of the connecting area between the western part of East Java and the city of Surabaya.

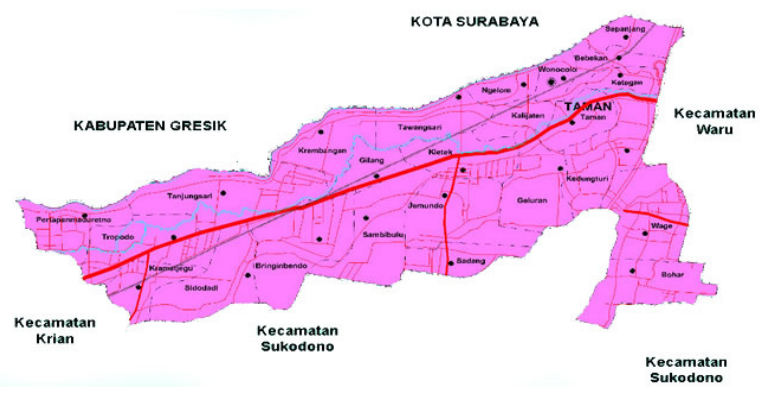

Picture 1. Taman district map 
Rusunawa Jemundo is a residential place that was established on the main market area of Puspo Agro. Therefore, this rusunawa is also known as Ruspo Agro rusunawa. There are two rusunawa complexes built in this area, and each flat consists of two buildings. So, a total of four buildings are located side by side and function as residents' flats for rent. To distinguish the two rusunawa complexes, the manager provided a guardrail as well as a different paint color. There are two buildings painted red, and two other buildings painted blue.

The difference can also be observed from the condition of the building, the residents of the flat, and the facilities available between the two. The atmosphere in the red flat looks neat and clean, there is almost no trash piled up and scattered around the building, the paint color that covers the tempok walls still looks fresh. At the front of the building, you can see vines hanging from each floor guardrail. From the ornamental plants, drooping stalks resemble curtains, making this residence look more beautiful from a distance. In addition, all rooms in these two buildings are air-conditioned that keep the room cool. The residents who live in the flat are refugees of foreign citizenship.

The opposite condition occurs in the blue flat, which is inhabited by the Shia Sampang community with the status of being refugees in their own country. They have occupied these two buildings about 8 years ago, and now the colors of the walls start to have faded color and peel. In addition, the condition of the floor has many holes and cracks. The two buildings, each consisting of five floors with 76 rooms in block A, and 76 rooms in block B. So, the total number of rooms in this flat is 152 rooms. However, not all rooms can be occupied by the Shia community, because some have been occupied by tenants. Based on information from Tajul Muluk, there are 81 families of the Shia community living in the flat with a total of 330 inhabitants. ${ }^{12}$ Each family occupies one room measuring $6 \times 6$ meters, most of which are in block $\mathrm{A}$, and the rest are in block $\mathrm{B}$.

They use one room, as bedroom, living room, even including the kitchen and bathroom. They do almost all household activities in one room, from sleeping, receiving guests, cooking, to bathing and washing clothes. For families with many members, living in a room is not an easy matter. They are required to organize the limited space neatly as well as possible,so that it can accommodate all the family members and various household items. Therefore, some of them complained about this as expressed by Hamama's mother;

${ }^{12}$ Tajul Muluk, Interview, December 4, 2017. 
"Yes, one room is for one family, but for a family with children it doesn't fit. Especially if someone is already married, it's confusing about not having a place, sleeping next to the father and mother is only bordered by curtains so you don't see it." ${ }^{13}$

However, the flats are safer and more livable than in the Sampang Sports Hall. At that time, there was no room for privacy, a total of 330 refugees shared one room. They stayed at the Sampang Sports Hall with limited and undecent facilities. As a result, some of them got ill and malnourished..$^{14}$

Outside the building, the air of the Rusunawa is cool due to the wind which blows from all directions. There is a large area in front of the building which is utilized for the residents' activities. This courtyard, as if it was split in half by a paved road with a width of approximately 2 meters. The base of this road is located at the gate adjacent to the security post, while the end is the flat building. Vehicles from the residents or visitors are line up at the yard. Not far from it, on the right side of the building there are chicken and goat coop with the size about $3 \times 4$ meters made of bamboo and wood. On this area, there are also trees and plants that are deliberately planted by the managers and residents of the flat. There are at least two trees that grow behind the security post with a height of approx 10 meters. Vegetables and spices such as eggplants, shallots and chillies are grown by the residents. This Rusunawa is surrounded by rectangular iron fences with a height of adults' shoulder.

Afternoon is the busiest time in rusunawa. The temperature outside the building is not so hot that the residents feel comfortable to do activities outside such asconversing with fellow residents, feeding livestock, or watching their children playing. At the gate of the flat, you can see the residents going back and forth to the flat, crossing the paved road using a vehicle or just walking. Most of those who enter the rusunawa area are women aged around 35-45 years, wearing large clothes that reach their ankles, and cover their heads with a large veil that extends to the chest. Such appearance is a characteristic of women in the Shia community. Meanwhile, adult men usually wear a sarung, koko (long sleeved moslem wear) and kopyah (moslem cap). It is in contrast with the appearance of the residents who generally wear shorts and t-shirts when doing activities in the flat. This difference in appearance is not a problem for the residents of the flat, even they are quite familiar with each other as they greet each other when they meet at the gate.

\footnotetext{
${ }^{13}$ Hamamah, Interview, December 14, 2017.

${ }^{14}$ Masykuri, Di Balik Dinding Rusunawa, p. 8-9.
} 
In the flat yard, the playing ground seems to be prepared for the children in the afternoon. They are seen playing seesaw and rope jumping. There are also those who are happily playing on the swing, shouting while closing their eyes as their bodies sway quickly. In addition, there are also those who looked agile when they climb the cherry tree behind the security post, and pick the ripe fruit to eat. Towards evening, the atmosphere outside the building is getting busier with the shouts of the boys who started running and chasing each other, circling the courtyard with sweat pouring out. The sound of the boy's laughter can be heard between the buildings so all the residents can hear it.

\section{The Causes of Discrimination and Expulsion}

The movement of the Shia community from Sampang Sports Hall to Rusunawa in Sidoarjo Regency is a serious problem for their community. This is because resettlement is not only a matter of place, but also cultural, social and political conditions. In reality, a few years after leaving their hometown, the Shia community had to experience complex social problems. They face social problems due to cultural and geographical differences from an agrarian-communal society to an industrial society in Sidoarjo. It is not easy for them to accept that reality, but they are forced to adapt socially. These complex social problems are caused by discrimination and misguided discourses by government institutions which from the beginning classified Shia as a heretical group.

\section{Labelling as Heretical}

Deviance labelling is the most serious problem for the Shia Sampang community. This began when a heretical discourse was constructed by the Fatwa of the MUI of Sampang Regency No. A-035/MUI/Spg/I/2012 and followed by the Fatwa of the MUI of East Java Province No. Kep-01/SKF-MUI/JTM/I/2012 dated January 21, 2012. The essence of the fatwa is the affirmation that the Shia teachings developed in Sampang Regency are deemed to have injured and tarnished the religion of Islam and recommended that the central, provincial and district governments take an action, emphasizing the deviant Shiite sect. ${ }^{15}$

This heresy labelling was later strengthened by Pergub No. 55 of 2012 concerning Fostering of Religious Activities and Supervision of Cults in East Java. This regulation states that all

${ }^{15}$ Dewan Pimpinan MUI Jatim, Fatwa danKeputusan MUI tentang Ajaran Syiah (Surabaya: MUI Jawa Timur, 2012), p.78. 
religious activities and teachings that are not in line with the principles of religious teachings are heretical teachings, and therefore it must be ensured that such activities cannot be continued. This regulation also requires everyone to report any activities that lead to this heretical teaching, and determines sanctions for anyone who spreads it. ${ }^{16}$

These fatwas and regulations are discoursed on truth, claims that are produced by the government itself and disseminated to the public. It can be also presumed to control the behavior of society, especially the Shia community. Through this discourse, the government has categorized behavior, between deviant and not heretical, right and wrong, normal and abnormal, to sin and reward. In fact, this kind of discourse may not reflect a democratic life. This discourse also slowly shifts the life of minority groups in their own country. This is what Michel Foucault (1926-1984) might say, power now does not work through oppression, but through normalization and regulation, punishing and shaping a disciplined public. The public is not controlled through power that is physical, but has been controlled. ${ }^{17}$

What has been experienced by the Shia Sampang community is a reflection of how the perverted discourse produced by the government and religious elite does not contain social justice. The deep inner pressure by the Shia Sampang community when they were evicted from their hometown, then temporarily displaced (GOR), and now in the Sidoarjo rusunawa is a consequence of a misleading discourse. Now that deep trauma has changed almost all aspects of their life. Their belongings, relatives and homeland just disappeared. In addition, intimidation from community groups because they feel that they have justification from the fatwa and government reports has worsened the lives of the Shia Sampang community. However, within their rocky journey, some people help them on the basis of humanity.

Their life in the rusunawa is slowly and surely getting better, accepted as their nigthbours in the community. They are not considered as others, or to borrow Emmanuel Levinas's term called "the other". ${ }^{18}$ For them, living in harmony in a flat will be more beautiful than living in

${ }^{16}$ Masykuri, Di Balik Dinding Rusunawa, p. 39.

${ }^{17}$ Eriyanto, Analisis Wacana: Pengantar Analisis Media (Yogyakarta: LKiS, 2011), p. 67.

${ }^{18}$ The concept of "the other" has actually been known for a long time. Since the time of G.W.F.Hegel (1770-1831), where he once said every personal consciousness will always pursue the death (consciousness) of 'others' (or others). But other content was first created by Emmanuel Levinas (1906-1995), a philosopher from France. In postcolonial theory, other terms are also frequently used and are important to describe the identity of the subject. Others refer to a subject whose position as a human is marginal. In the study of tolerance, others are a minority group. Lim Sing Meij, Ruang Sosial Baru Perempuan Tionghoa: Sebuah Kajian Pascakolonial (Jakarta: Yayasan Obor Indonesia, 2009), p. 2. 
their own community, but they are considered as a marginalized group whose existence must be eliminated.

\section{Uprooted from its Cultural Roots}

As a result of the labeling above, Shia community had actually experienced social pressures. Apart from being labeled as followers of a heretical sect, they also experienced social conflicts with people around them, and were expelled from their homeland by their close relatives. Since then they have been an outcast and faced with social environments they have never imagined and prepared for the resettlement. They are faced with a situation, both socially, culturally, economically, and ecologically.

In the refugee camp, they started to become strangers. There is no familiar environment where they grow up with a strong cultural aspect. In refugee camps, they live otherwise. They live in a one-room flat which is very small that can be occupied by one family. They are in the middle of an urban environment, or an industrial area with a variety of Javanese-speaking people. There is no tanèyan lanjhâng (long yard), there is no rice field or moor as a place for their daily activities like in the old place.

Likewise, ecologically, in Madura they build houses in a place consisting of four or five families who are still siblings, surrounded by a green wall or fence called kampong meji. So this settlement pattern has an effect on social organization. Beside that, as devout Muslims, each of them also has a prayer room (surau). The surau occupies a central position in each of their villages where kiai teaches the community and kiai becomes the mullah in each place on several meji villages. ${ }^{19}$ Meanwhile, in the refugee camps, they lived in a place that is ecologically different from the meji village above.

The next is a communication culture that is linguistically different. For them, this is a serious problem, because they have to mingle with the community, most of whom have Javanese cultural backgrounds. Their language is Javanese. Meanwhile, the Shia community speaks Madurese. As a new resident, Shia community face a language problem as most of them cannot speak Javanese and Indonesian which is caused by two factors; the first is the low level of education. The education they took was religion, so the general knowledge they had was quite low.

\footnotetext{
${ }^{19}$ Kuntowijoyo, Perubahan Sosial dalam Masyarakat Agraris Madura (1850-1940) (Yogyakarta: Mata Bangsa, 2002), pp. 588-9.
}

48 The Cultural Negotiation of Being Shia and Madurese| Abdus Sair \& Yelly Elanda 
Second, they speak Madurese, including in their daily activities. Madurese is their mother tongue andit is difficult to speak other languages. The difference in language and knowledge makes the adaptation process of the Shia community quite slow. This condition makes Shia Sampang community experience a cultural shock, and this cultural shock is due to the uprooting of their culture from their hometown. They are then exposed to a new, sociologically different culture.

\section{Profound Trauma}

Another result of the labelling as misguided above is also experiencing a deep sense of trauma due to expulsion, especially since those who did it were their relatives, their own neighbors. Relatives and neighbors who are usually the main lifeline when they are experiencing difficulties, this time they want to kill them by burning their houses. Relatives and neighbors who have been a home, joking in the middle of their spare time have forcibly evicted them from their hometown. The tears and bitterness felt by Shia groups are now a reason for them to "fear" strangers. They are afraid that the incident will happen all over again, especially people who they know and trust only push them away, especially when dealing with strangers they never know.

The trauma seems to linger and one day it can come out. Eight years after the event, they can not bury all the experiences. They take a long time to get rid of that fear. They are in tears almost all the time, especially when they are forced back into reminiscing about the past. In simple terms, their current situation can be described as what Mokh Hariyadi Eko Romadon said when describing the passionist memory of the 1965 battle of former political prisoners, "it hurts to remember, it's hard to forget." ${ }^{20}$ That is why, they do not easily accept starngers who visit the rusunawa just to explore how they are currently living.

That deepest fear can certainly be understood because they have experienced physical and verbal abuse. They were forcibly evicted from their hometown. Nothing was left of all their inheritance, their houses, treasures and rice fields had been scorched. What remains may be only obedience to the figure of the ustâdz who is now their leader. Obedience to ustâdz has made them lead a solitary life in the refugee camp. Everything that is related to their fate depends on the ustâdz. Perhaps because of that, all aspects of their life were left to the ustâdz.

${ }^{20}$ Mokh Hariyadi Eko Romadon, Negara dan Kekerasan pada Tragedi Gerakan Tiga Puluh September (G-30 S): Studi Memoria Passionis Perempuan Eks Tapol 1965 (Dissertation, Universitas Airlangga, Surabaya, 2012) 
What ustâdz said was also considered a mirror of their view, including following the rules set by ustâdz, namely not having an affair or marrying someone outside the Shia community. It is also a matter of work, not running a business because it is considered interfere with its original goal, namely returning to their hometown.

\section{The Cultural Negotiation}

As stated above, the Shia Sampang community in refugee camps is a community that has been expelled, experiencing many complex problems. Apart from having to leave their hometown, they also have to lose their homes, land and other possessions. The complexity of the problem is really difficult for them to deal with, while they want to raise their children, and lead a normal life. In this process, they have to negotiate with the circumstances. Negotiation is an everyday social practice. There are at least three negotiations, namely to remain a good Madurese; to be obedient to kiai (ustâdz), to continue to work as a cultural principle, and to keep looking for a cultural way back.

\section{Obey Kiai (Ustâdz)}

Like the Madurese in general, the position of Kiai Tajul Muluk occupies a very central position. He became a reference for any Shia community there, including the question with whom they should have social relations. This shows that traditionally, Muluk is a local leader who has great, absolute and charismatic authority. Muluk's charisma is clearly still significant which makes Shia worshipers in refugee camps have to submit and obey. This is because they cannot get blessings.

For example, in terms of social relations, on the advice of the kiai, it is recommended that they gather together, getting involved, and becoming part of a network of social relationships in a new environment is the path they must take. Initially, these social networks and relationships were traditionally carried out on the basis of hereditary social experiences and shared beliefs in the divine dimension. This is because they both come from one area in Sampang district, namely from the villages of Nangkernang, Karang Gayam and Gading Lok hamlet, Bluru'an Village, Karang Penang District which is a Shia religion. 
But in the process, self-involvement in a social network is encouraged by building relationships which is carried out with the principle of voluntary, equality, and civility. ${ }^{21}$ Muluk's instructions to unite themselves in a synergistic relationship pattern with other communities are for the sake of existence, especially when they realize that they are in uncertainty, both as Indonesian citizens, Indonesian Muslim communities, and humans who should be treated fairly with all of social attributes they have.

In fact, with these social relations, both with fellow refugees, as well as with other rusunawa tenants, they have become a savior valve. If in the past, neighbors or relatives who lived in their hometown were their saviors, now the safety valves are fellow Shia refugees and other residents in the flat. These kinds of social practices are a form of cultural negotiation to be a good Madurese.

However, the social relations they do are still limited by their own internal rules. This means that social relations do not run freely as they should. The standards are included; they are not allowed to date, cannot be married to non-Shia communities, cannot be too close to other communities to worry about provocation, nor can they enjoy entertainment offered by the government or private parties around the flat. ${ }^{22}$ This restriction, it seems strange, but they live it as a form of obedience to the ustâdz.

Obedience to the ustâdz or kiai is cultural obedience which represents the hierarchical obedience, submission, and surrender to the four main figures in life, especially in religious praxis. The opportunities for these figures are Bhuppa', Bâbu, Ghuru, bân Rato (Father, Mother, Teacher, and Government Leader). These main figures are the hierarchical obedience of the Madurese people that shows its form in the praxis of everyday socio-cultural life. ${ }^{23}$ And in this way they actually still want to show that they are good Madurese, Madurese who do not change by remaining obedient to the teacher who is sami'nâ wa atha'nâ (we hear and we obey).

${ }^{21}$ Jousairi Hasbullah, Social Capital: Menuju Keunggulan Budaya Manusia Indonesia (Jakarta: United Press, 2006)

22 Syaiful, Interview, December 14, 2017.

${ }^{23}$ A. Latief Wiyata, Madura yang Patuh: Kajian Antropologi Mengenai Budaya Madura (Jakarta: CERIC-FISIP UI, 2003), p. 1; and Taufiqurrahman, "Identitas Budaya Madura," KARSA: Jurnal Sosial dan Budaya Keislaman, vol. XI, no. 1 (April, 2007): 3, https://doi.org/10.19105/karsa.v11i1.143. 


\section{Working as a Cultural Principle}

Each refugee has been given allowance in cash amounting to 700,000 per person. Each family will receive a different amount of money based on the number of family members. This allowance was taken from the Regional Government Budget (APBD). Financial assistance is under the Ministry of Welfare, while security protection under Kesbangpol coordinates with the Indonesian National Armed Forces (TNI) and Police, while the cost of electricity, water, maintenance and rent is financed by Public Works Department of Human Settlements (PU Cipta Karya), while Social Insurance Administration Organization (BPJS) under the Ministry of Health, education services is under the Education Department, while the daily services that look after and assist the refugees are under the responsibility of the Regional Disaster Management Agency (BPBD). ${ }^{24}$

This means that their lives in refugee camps have been guaranteed through the role of the government. However, the assistance provided by the provincial government through a living allowance (Jaminan Hidup) does not stop the Shia community from working. They continue to work for their family and community. The impulse was not only due to economic factors, but another impulse, namely the principle of having to work which always stuck with them and most Madurese in general. As Hary Yuswadi said, Madurese do tend to have a tough character (high temperament), those are open, have very strong kinship ties and hardworking. ${ }^{25}$ These characteristics are common and perhaps this is why they survive in limited conditions.

In addition, there are other values that are also often practiced by the Madurese, namely the values of competition, achievement, candor and honesty, which are reflected in proverbs, such as abhântal ombâ' asapo' angen, abhântal syahâdât asapo' iman, which means "padded with waves covered in the wind, pillowed on shahada covered in faith". This is the value of the Madurese people who have a tireless enthusiasm for working to support their families. For them, work is a form of worship that must be carried out while doing worship is martyrdom. This belief strengthens their enthusiasm and persistence to work tirelessly. This is a proof even though they are in the refugee camps and get a living allowance, they still work.

Another saying is that bhângo' jhubâ' $\hat{a}$ è adâa' ètèmbhâng jhubâ' è budi, which means that it is better to be bad in front of than bad at the back, it can be interpreted that in social life,

\footnotetext{
${ }^{24}$ Cahyo Pamungkas, Mereka yang Terusir (Jakarta: Yayasan Obor Indonesia,2017), p. 27.

${ }^{25}$ Hary Yuswadi, Melawan Demi Kesejahteraan (Jember: Kompyawisda JATIM, 2005), p. 23.
} 
Madurese need to solve every problem as clearly as possible. This shows the value of honesty that must be upheld. The proverb "bad in front of the bad behind" can be interpreted that all matters of social life must be clear from the start. Apart from that, the proverb is better understood as something that must be followed by the parties making the agreement.

Another proverb is kar-ngarkar nyolpè, which means to peck, peck is a reflection of the character of the Madurese who are willing to take the pains and patience carrying out seemingly trivial activities and reap the results that may be insignificant. For the Madurese, there is no humiliating job as long as it is lawful and blessed by Allah.

From this, it can be understood that values created in the Madurese community group above which weigh to the values of competition, achievement, candor and honesty, has made the Madurese community so far develop and exist much faster than the community groups who have always avoided candor, competition and achievement.

The Shia community in refugee camp also seems to share these characteristics. They do not only rely on the assistance provided by the government, but also work hard to make ends meet. During their time at the refugee camps, they worked as satay sellers, coconut peel workers, grocers, phone credit sellers and barbers. They do all the work because of the high work ethics and values that have been held as principles. This work ethic has been shown by the Shia refugees, as mentioned above. And as freelance workers peeling coconut, or cleaning coconut meat which is put into eight barrels filled with clean water and then drying, they are paid Rp. 150.

\section{Finding a Cultural Way Home}

As mentioned above, the Shia Sampang community has been living in refugee camps for eight years. They consist of 38 families or about 380 people. They are led by a figure who has been respected by the community, namely Ali Murtadho alias Tajul Muluk. Although they have prominent figure, they are still a weak social group because they have tolive far from their homeland.

As an outcast, various efforts have been made to seek justice, namely returning to their hometown. But these efforts often find deadlocks. Starting from meeting with President Susilo Bambang Yudhoyono (SBY), conducting actions, campaigns, publications and movements for 
justice initiated by NGOs, academics and mass organizations, ${ }^{26}$ to religious and cultural reconciliation. ${ }^{27}$ The roads taken to find a way home.

After eight years living in refugee camps, the Shia Sampang community began to look for other ways, namely by pledging themselves to "repent" or return to Sunni teachings. This effort can be a compromise after finding a dead end from the various efforts they have made, both formally and informally. This effort could also be a humanitarian one, given that the Shia community in refugee camps experience isolation and exile. Muluk admitted his mental state when being interviewed by Raja Eben Lumbanrau, as follows;

"We only live here, just like the immigrants next door. Just go to the market to work, after that go home, get together among fellow refugees. There are no associations with outsiders. Feeling alienated, I just can't help it," said Tajul Muluk that afternoon when talking with us in the courtyard of the fourth floor of the flat which was used as a place for prayer and gathering. ${ }^{28}$

They admit this because they are tired of the limited life, not being free human beings. They miss their old life when togetherness and friendship with the residents of their village in Sampang, Madura, were good. Therefore, repentance is the best way for them to find a way to their hometown. Returning to their hometown is actually the biggest dream of those who are now in their old age and hope to spend it in their hometown. This effort has been made since mid-March 2020 by embracing Sunni teachings. Then on September 10, 2020, he sent a official letter to the Sampang Regency Government containing a request for a pledge (bai'ah) to return to Sunni teachings. ${ }^{29}$ Finally, the realization of the "repent" vow was carried out on Thursday, November 5, 2020 at the Sampang Regency Hall, which was attended by 274 followers. ${ }^{30}$ The rest remained devout Shia followers who refused to embrace Sunni teachings.

From the findings above, there are several things that need to be discussed regarding their experiences as an isolated minority group, the social problems they experience, and their efforts to find their way back home. Our statement regarding the above findings can be explained as follows:

\footnotetext{
${ }^{26}$ Ade Mas Satrio Gunawan, Politik Perlawanan Pengungsi Syiah Sampang di Jemundo dalam Pemenuhan Hak Sipil dan Politik (Thesis, Universitas Airlangga, Surabaya, 2012)

${ }^{27}$ Pamungkas, "Mencari Bentuk Rekonsiliasi"

${ }^{28}$ Raja Eben Lumbanrau, "Pengungsi Syiah Sampang Mencari Jalan Pulang: Siap Dibaiat sebagai Suni, Kisah Tajul Muluk dan Pengikutnya, 'Diasingkan, Dipenjara' Bertahun-tahun tanpa Kepastian,” BBC, November, 2, 2020, https://www.bbc.com/indonesia/indonesia-54550916.

${ }^{29}$ Ibid.

30 Anonymous, "Tajul Muluk Beserta 274 Pengikut Syiah Resmi Berikrar Kembali ke Aswaja,” Duta, November, 5, 2020, https://duta.co/tajul-muluk-beserta-274-pengikut-syiah-resmi-berikrar-kembali-ke-aswaja.
} 
First, the Sampang Shia minority group is a serious problem for this nation, especially in the province of East Java. The expulsion experienced by the Shia Sampang community shows that East Java is not a province that is free from various effects of strengthening anti-pluralism sentiment. The expulsion actually shows that East Java is part of efforts to uniformity and destroy diversity.

In addition, the act of expulsion is an offense that cannot be accepted for any reason, either for religious heresy or for morality. These actions violate human rights, which are regulated in the 1945 Constitution, especially in article $28 \mathrm{G}$ paragraph 1, every person has the right to protect themselves, family, honor, dignity and property and those under their control, and are entitled to a sense of security and protection from the threat of fear to do something that is a human right.

Therefore, the elimination of minorities should be the government's concern in order to minimize the expulsion. The government has the authority to protect every citizen, from all acts of violence or expulsion, either directly or indirectly. The government also has an obligation to create life through legal certainty. Instead of becoming an actor in all acts of expulsion, either through recommendations containing accusations and blasphemy or by discriminatory regulations. This condition is mentioned by Ahmad Najib Burhani ${ }^{31}$ in his dissertation, the government as state power and alliances between religious authorities often become judges and appoint themselves as religious police and fatwâ enforcers.

Second, social problems are experienced by the Shia community during their expulsion. As an exiled community, the position of the Shiites is actually very weak. They do not have any strength, except solidarity. They have lost everything, from being uprooted from their cultural roots, stigma as a cult group, to very profound trauma. In such conditions, social ties are one of the social assets that can make them survive. Social ties are both reinforcing and binding in facing everyday social problems.

Based on this view, the Shia Sampang community has this solidarity because it is supported by a strong culture and religious beliefs. They are Madurese who sociologically have solitary family ties, a social structure that places teachers or kiai as highly respected figures. The position of such teacher or kiai is the foundation that ultimately keeps the weak Shiite

\footnotetext{
${ }^{31}$ Ahmad Najib Burhani, When Muslims are not Muslims: The Ahmadiyya Community and the Discourse on Heresy in Indonesia (Dissertation,University of California, Santa Barbara, 2013), p. xv.
} 
community strong. That is, the social structure of the Madurese and strong beliefs are a value or norm that enables them to work together. In another sense, they can survive because they have that social capital.

The social capital referred to is also the same as what Pamungkas ${ }^{32}$ expressed as social resilience when he explained religious minority groups to Shia refugees in Sidoarjo and Ahmadiyah refugees in Mataram. However, we would like to add that the social resilience of Shia refugees is not only shaped by theological beliefs, especially the Karbala doctrine as stated by Pamungkas. This study shows that, social resilience is also largely shaped by culture, and strong local Madura values, such as solidarity between people (Madura), working as a cultural principle, and being obedient to teachers. These local values become the same engine as forming social security, which until now is still a Shia Madurese.

Related to this, the local values above also serve as cultural negotiations, such as being a good Madurese. They are indeed Shia, but they remain obedient to the kiai (ustâdz), continue to speak Madura, continue to work as a cultural principle, and live life while looking for a way home. These local values are clearly an instrument that allows them to remain recognized as Madurese. These local values are actually also a point of our attention to solve their problems. As Collins ${ }^{33}$ explained, that social conflict is not about external unity and imperatives, but rather about patterns of interaction. This means that the settlement of the Shia conflict in Sampang is not far from these local values whose representation is in the form of interaction patterns.

Third, their quest to find his way home. Looking at the facts above, it is difficult to explain that the government is here to carry out its functions. In the case of Shia Sampang, the government is actually not able to carry out its functions properly, namely as a protector, unifier and law enforcer in social life. The government, in fact, does not have the courage to carry out this function because it is socially inferior to the social and cultural structure of society. This condition makes the Shia community does not find the way home, except by "repenting". This is the only way that the Shia community can take to become free, be able to gather with family, be able to return to their hometown, or return to a normal life. Or in other words, this is a "compromise" path for the Shia community, because there is no other way.

\footnotetext{
32 Pamungkas, "Social Resilience," 251-278.

${ }^{33}$ George Ritzer and Douglas J. Goodman, Teori Sosiologi Modern (Jakarta: Prenada Media, 2003), pp. 1601. 


\section{Conclusion}

The Shia Sampang community is a minority group that is vulnerable to acts of violence by anyone, anytime and anywhere. Expulsion, punishment experienced by them, and exile to a place far from their hometown are the most obvious forms of violence.

As a state law, violence against Shia Sampang minority group cannot be justified for any reason. The government should act on behalf of the state to protect all citizens by enforcing the law in line with the prevailing laws and regulations. However, the Shia Sampang case emphasizes that the government cannot yet be called capable of carrying out that function because the power of the state (government) is weaker than the power of mass organizations, culture and social structures in Sampang Madura.

As a result, they cannot relish the right to normal life as a minority group. On the other hand, the Shia Sampang community must live in refugee camps, a place of "exile" which is against human rights. They experience complex social problems, such as; uprooted, branded as a cult, and deep trauma.

These complex social problems drive them to negotiate with the situation while still upholding the principles and ethics of the Madurese who obey the kiai (ustâdz). These negotiations are social practices, such as obeying the kiai, continuing to speak Madurese, continuing to work based on cultural principles, and living life while looking for a way home.

All of these happens because of another very important factor, namely, the strong values of solidarity that fellow refugees have. This social bond has tied them to help each other. The value of solidarity at the same time is a lifesaver valve that keeps them alive today.

Even so, they still hope to find their way back home. Their hometown is their life. They have strong social ties to their homeland. Various attempts to find a way back have been made, including hoping through the role of the government, but in fact, end up in vain. This is because government power is socially less powerful than the social and cultural structure of the Madurese community. There is no other way, except to follow their demands to join the Sunni sect. "Repent" is a compromise so that they can live freely, be with family, or return to normal life. "Repenting" is the last way that can be taken to find a way back home, although in fact this is also a problematic way. 


\section{Reference}

Affan, Heyder. "Mungkinkah rekonsiliasi di Sampang?" BBC, August, 1, 2013, https://www.bbc.com/indonesia/laporan_khusus/2013/08/130731_lapsus_syiah_sidoarjo _rekonsiliasi

Andi. "Komunitas Syiah Sampang 7 Tahun di Pengungsian, Noda Hitam di Kening Negeri Toleran.” Ahlul Bait Indonesia, August, 27, 2019, https://www.ahlulbaitindonesia.or.id/berita/index.php/s13-berita/komunitas-syiahsampang-7-tahun-di-pengungsian-noda-hitam-di-kening-negeri-toleran.

Anonymous. "Tajul Muluk Beserta 274 Pengikut Syiah Resmi Berikrar Kembali ke Aswaja." Duta, November, 5, 2020, https://duta.co/tajul-muluk-beserta-274-pengikut-syiah-resmiberikrar-kembali-ke-aswaja

Burhani, Ahmad Najib. When Muslims are not Muslims: The Ahmadiyya Community and the Discourse on Heresy in Indonesia. Dissertation, University of California, Santa Barbara, 2013.

Cresswell, John W. Penelitian Kualitatif dan Desain Riset: Memilih di antara Lima Pendekatan. Yogyakarta: Pustaka Pelajar, 2015.

Dewan Pimpinan MUI Jatim. Fatwa dan Keputusan MUI tentang Ajaran Syiah. Surabaya: MUI Jawa Timur, 2012.

Eriyanto. Analisis Wacana: Pengantar Analisis Media. Yogyakarta: LKiS, 2011.

Gunawan, Ade Mas Satrio. Politik Perlawanan Pengungsi Syiah Sampang di Jemundo dalam Pemenuhan Hak Sipil dan Politik. Thesis, Universitas Airlangga, Surabaya, 2012.

Hasbullah, Jousairi. Social Capital: Menuju Keunggulan Budaya Manusia Indonesia. Jakarta: United Press, 2006.

Kuntowijoyo. Perubahan Sosial dalam Masyarakat Agraris Madura. Yogyakarta: Mata Bangsa, 2002.

Lumbanrau, Raja Eben. "Pengungsi Syiah Sampang Mencari Jalan Pulang: Siap Dibaiat sebagai Suni, Kisah Tajul Muluk dan Pengikutnya, 'Diasingkan, Dipenjara' Bertahun-tahun tanpa Kepastian.” BBC, November, 2, 2020, https://www.bbc.com/indonesia/indonesia54550916

Masykuri, Romel et. al. Di Balik Dinding Rununawa: Mengungkap Pengalaman Komunitas Syiah Sampang di Pengungsian. Yogyakarta: Penerbit Sulur, 2018.

Meij, Lim Sing. Ruang Sosial Baru Perempuan Tionghoa: Sebuah Kajian Pascakolonial. Jakarta: Yayasan Obor Indonesia, 2009.

Munawaroh, Mundiroh Lailatul. Penyelesaian Konflik Sunni-Syiah di Sampang Madura. Thesis, Universitas Islam Negeri Sunan Ampel, Surabaya, 2014.

Pamungkas, Cahyo. Mereka yang Terusir. Jakarta: Yayasan Obor Indonesia, 2017.

Pamungkas, Cahyo. "Mencari Bentuk Rekonsiliasi Intra-Agama: Analisis terhadap Pengungsi Syiah Sampang dan Ahmadiyah Mataram.” Epistemé: Jurnal Pengembangan Ilmu Keislaman, 13 (1): 114-147, https://doi.org/10.21274/epis.2018.13.1.113-147. 
Pamungkas, Cahyo. "Social Resilience of Religious Minority Group: Study on Syiah Refugees in Sidoarjo and Ahmadiyah Refugees in Mataram." Ulumuna: Journal of Islamic Studies, 19 (2): 251-278, https://doi.org/10.20414/ujis.v19i2.418.

Panggabean, Rizal. "Mungkinkah Rekonsiliasi di Sampang?" CSPS Universitas Gadjah Mada, March, 17, 2017, https://csps.ugm.ac.id/2017/03/17/mungkinkah-rekonsiliasi-di-sampang2/

Pujianto, Eko. "Pengungsi Syiah Dapat Sertifikat Tanah dari Gubernur Khofifah.” Indonesia Inside, February, 2, 2021, https://indonesiainside.id/news/nusantara/2021/02/02/pengungsi-syiah-dapat-sertifikattanah-dari-gubernur-khofifah.

Romadon, Mokh Hariyadi Eko. Negara dan Kekerasan pada Tragedi Gerakan Tiga Puluh September (G-30 S): Studi Memoria Passionis Perempuan Eks Tapol 1965. Dissertation, Universitas Airlangga, Surabaya, 2012.

Ritzer, George and Douglas J. Goodman. Teori Sosiologi Modern. Jakarta: Prenada Media, 2003.

Taufiqurrahman. "Identitas Budaya Madura." KARSA: Jurnal Sosial dan Budaya Keislaman, XI (1) 3, https://doi.org/10.19105/karsa.v11i1.143.

Wiyata, A. Latief. Madura yang Patuh: Kajian Antropologi Mengenai Budaya Madura. Jakarta: CERIC-FISIP UI, 2003.

Yuswadi, Hary. Melawan Demi Kesejahteraan. Jember: Kompyawisda JATIM, 2005.

Interviews:

Hamamah, Interview, December, 14, 2017.

Syaiful, Interview, December 14, 2017.

Tajul Muluk, Interview, December, 4, 2017. 